\title{
Gadus Esmarkii, Nilsson, the Norway Pout, an addition to the Fish Fauna of the English South-Western District.
}

\author{
By
}

Matthias Dunn, of Mevagissey, and Ernest W. L. Holt.

IN the summer months, for some years prior to 1887, very large quantities of Hake (Merluccius vulgaris) had been caught by trawlers beyond the entrance of the Bristol Channel, and landed at Plymouth. Knowing that such masses of hungry creatures would not be found continuously in any given locality without a heavy balance of smaller fish being in their neighbourhood as food for these hakes, I became anxious to know what these smaller fish were, and throughout the summer of 1888 I tried more than once to get at them through our fishermen, but failed.

In July, 1889, I desired my son Howard to visit the Plymouth Barbican, and notice the gutting of the hakes there and tell me the result. His report was that they had been feeding on small whiting (Gadus merlangus), and that single hakes had as many as ten whiting in their stomachs. I told him that I doubted if these small fish were whiting, and asked him to send the specimens at once, as I expected them to be the poutassou (Gadus poutassou) of Couch. I had recently had specimens of this fish brought me from thirty miles west of the Scilly Isles.

About a week afterwards my son sent me. seven of these little ones taken from the stomach of a pollack (Gadus pollachius) which had been caught in a trawl forty miles north-west of St. Ives. On giving them my attention, I was surprised to find they were not the poutassou nor any other Gadus I was acquainted with.

Hence I forwarded these two specimens to the Plymouth Biological Laboratory for further enquiry and research concerning this new species.

M. D. 
The credit of the discovery of the Norway pout in the south-western district, and of its recognition as distinct from any Gadus previously recorded in the local fauna, is entirely due to Mr. Dunn. My own share in the matter is confined to the specific identification of the material, a matter of small difficulty, owing to an extensive previous acquaintance with the species on the west coast of Ireland and in the North Sea.

Though the species has been discussed at some length as recently as $1895,{ }^{*}$ a short recapitulation of its history appears convenient.

Originally discovered by Esmark, in 1844, as an inhabitant of the Norwegian coast, its range was subsequently extended by Luitken to the Faröe Islands.

In 1888 it made its first appearance in British records, being found in comparative abundance by Günther among the fishes collected by Murray on the west coast of Scotland.

It was next recorded by myself, in 1890 and 1891, from the west coast of Ireland, where it occurred, during the Royal Dublin Society's survey, in considerable numbers, a great many of my specimens being found, as was the case with Mr. Dunn's, in the stomachs of larger fishes; and in $1892 \mathrm{I}$ was able to extend its range again, from the examination of stomach contents, to the Great Fisher Bank in the North Sea. It is therefore apparent that, in so far as regards the date of capture, $\mathrm{Mr}$. Dunn's specimens actually represent the second occurrence of the species within the British area.

It is not a shallow-water fish, having hitherto been found, or at any rate recorded, only between 26 and 144 fathoms, a fact which may partially account for its having so generally escaped attention at the hands of naturalists. Fishermen would naturally regard it with unconcern, since it never grows to a marketable size, and bears, moreover, a very close resemblance to a common and, from the market point of view, equally worthless form, Gadus minutus.

Probably it may prove to be common enough at suitable depths around our coasts, though it may perhaps not extend into the English Channel or further south, since our continental neighbours, who take a gastronomic interest in even smaller fish, would in such case be likely to have noticed it.

The specimens forwarded by Mr. Dunn to the Laboratory are two in number, and, taken as they were from the stomach of a pollack, are naturally not in the most perfect condition, though quite sufficiently so for identification. One, which is complete, measures $7 \frac{1}{4}$ inches in total length, while the original length of the other, which has lost

\footnotetext{
* Holt and Calderwood, Sci. Trans. R. Dub. Soc., v. 1895, ix. p. 431.
} 
the caudal peduncle, may safely be estimated as over eight inches. They are thus rather large examples.

Dr. Günther has called attention to the existence of two varieties of the species, of which the typical Norwegian forms were found to differ from the Scottish chiefly in the greater attenuation of the body and the greater size of the eye. The same difference was found to exist between the solitary specimen from below the 100 fathoms line and the smaller ones from lesser depths among the Irish survey collections. Without entering into details, it may suffice for the moment to remark that Mr. Dunn's specimens agree with the larger Norwegian and deep-sea Irish type, and not with the smaller Scottish and Irish variety.

E. W. L. H. 